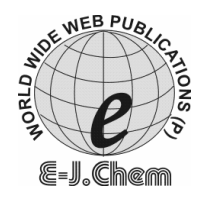

\title{
Binding of Dumbbell Oligonucleotides to MoMuLV Reverse Transcriptase: Inhibitory Properties of RNase H Activity
}

\author{
AJAY KUMAR \\ Guru Tegh Bahadur Institute of Technology, \\ G-8 Area, Rajouri Garden, New Delhi-110064, India. \\ ak.gupta59@rediffmail.com
}

Received 4 July 2009; Revised 17 November 2009; Accepted 10 January 2010

\begin{abstract}
Dumbbell oligonucleotides with loops of various chemistry were synthesized. Incubation of dumbbell oligonucleotides containing phosphorothioate bonds or trimethylene phosphate linkages in loops with S1 nuclease did not result in significant cleavage under conditions which led to the degradation of dumbbell oligonucleotide containing phophodiester bonds in the loops. The binding of reverse transcriptase of Moloney Murine Leukemia Virus (MoMuLV) was evaluated with all the five oligonucleotides. The protein binds to all the dumbbell oligonucleotides with similar affinity. The dissociation constants evaluated using PAGE band mobility shift assays were of the order of $10^{-7}$. The inhibitory properties of the retroviral RNase $\mathrm{H}$ activity was evaluated using ${ }^{3} \mathrm{H}-\mathrm{UTP}$ labeled RNA:RNA-DNA hybrid. It was found that the best dumbbell oligonucleotide, inhibitor contained phosphorothioate residues in both the loops. Our value studies demonstrated that this particularly designed oligonucleotide displays an $\mathrm{IC}_{50}$ of $18 \mathrm{nM}$ in its inhibition on the reverse transcriptase RNase $\mathrm{H}$ activity, a magnitude lower than that of first nucleotide reverse transcriptase of HIV-1, tenofovir, introduced by Gilead Science in the market.
\end{abstract}

Keywords: Dumbbell Oligonucleotides, MoMuLV Reverse Trascriptase, Inhibition, RNase H.

\section{Introduction}

Reverse transcriptase is a key enzyme for the life -cycle of retroviruses. It bears an RNA and DNA -dependent polymerase activity responsible for first strand and second strand DNA synthesis from the retroviral RNA genome. In addition, retroviral reverse transcriptase also possesses a ribonuclease $\mathrm{H}$ activity, an enzyme which cleaves the RNA strand of RNADNA hetroduplex. The retroviral RNase $\mathrm{H}$; i) degrades the RNA template following first strand synthesis, ii) generates primers for second strand synthesis and iii) eliminates the $t$-RNA primer ${ }^{1}$. 
These various steps are absolute prerequisites to the integration of the viral genetic information into the host cell genome. Therefore any ligand able to block the RNase $\mathrm{H}$ activity would prevent the development of retroviruses. Up to now a very limited number of molecules were shown to display RNase H inhibitory properties ${ }^{2,3}$.

Synthetic oligonucleotides, either conventional or chemically -modified, are widely used to block gene expression ${ }^{4}$. Antisense oligonucleotides were shown to prevent translation, splicing and reverse transcription ${ }^{5-7}$. Ribozymes have been designated that could cleave the viral $\mathrm{RNA}^{8}$. Triplex -forming oligomers have also been used in vitro to target polypurine sequence either the RNA or the DNA level ${ }^{9,10}$ Oligonucleotides sequence able to compete with the natural $t$-RNA primer and which could not be lengthened by the polymerase were demonstrated to block reverse transcription ${ }^{11}$. Oligonucleotide destroys which mimick the primer have derived from the primer $t$-RNA either as phosphorothioates or phosphorodithioates ${ }^{12}$. Alternatively, oligonucleotide sequences (aptamers) extracted by in vitro selection procedures from a random library displayed inhibitory properties of reverse transcriptase activities ${ }^{12}$ through binding to the protein. The decoy (or sense or dumbbell oligonucleotide) approach represents an alternative use of synthetic oligonucleotides in a rational protein-targeting concept. In this case, oligonucleotides carrying the recognition sites for specific DNA- or RNA-binding proteins (e.g., regulatory proteins, repair or replication enzymes), are used as competitive inhibitors to titrate their targets, and thus, to inhibit their normal functions (for example, DNA replication, activation of gene transcription etc.).

The efficiency of the decoy competition approach has also been demonstrated in several cellular models. The expression of a CAT reporter gene driven by the MBP gene promoter in glial cells was inhibited by the co-transfection of decoy phosphodiester oligonucleotides containing the MB1 binding site ${ }^{22}$. Other examples of decoy inhibition of CAT expression driven by different promoters in transiently transfected cells are the use of NF-kB or Oct- 1 phosphorothioate decoys in B cells transformed by Epstein-Barr virus $^{23}$, HNF-1 phosphodiester decoys in the C33 human epithelial tumor cell $\operatorname{line}^{24}$ and NF-kB., a b -anomeric decoys in HeLa cells ${ }^{25}$. Decoy oligonucleotides have also been used to assess or confirm the cellular role of a given transcription factor. For example, microinjection of CRE or AP- 1 decoy oligonucleotides in 3T3 or human Hs68 fibroblasts blocked the cell cycle normally induced by both regulatory proteins ${ }^{26}$. Also, NF-kB decoy phosphorothioate oligonucleotides inhibited PMA-induced changes in the expression of cell adhesion molecules in HL60 and HUVEC cells ${ }^{27}$. The functional role of PU.1 in hematopoietic cell development was similarly demonstrated by the use of phosphorothioate PU.1 decoys in CD34+ cells ${ }^{28}$. Recently, the ability of decoy oligonucleotides to block gene expression in vivo has been demonstrated. E2F decoy oligonucleotides able to modulate the expression of E2F-dependent genes were shown to inhibit smooth muscle proliferation and vascular lesion formation in an in vivo model of rat carotid injury ${ }^{29}$. The double-strand decoy DNA oligomers have been used for the inhibition of gene expression ${ }^{30-36}$. Recently the interaction of human DNA topoisomerase I (topo 1) with certain specific sequence dumbbell-shaped circular oligonucleotides has been reported and has been demonstrated that this particularly designed oligonucleotide displays an $\mathrm{IC}_{50}$ value of $9 \mathrm{nM}$ in its inhibition on the activity of human topoisomerase $\mathrm{I}$, a magnitude smaller than that of camptothecin, an anticancer drug currently in clinical use ${ }^{37}$. Sequence-independent inhibition of RNA transcription by DNA dumbbells and other decoys has also been reported ${ }^{38}$. 
In order to ensure that decoys will be potent drugs, the oligonucleotide-target interaction must have high affinity and specificity and the oligonucleotides must be stable in the biological environment. Phosphodiester oligonucleotides are natural candidates for biological applications both in terms of affinity and specificity, with the additional advantage of being devoid of intrinsic cytotoxicity. However, in vivo use of oligonucleotides is severely hampered by their sensitivity to nuclease degradation. This is particularly important for single stranded oligonucleotides since both in cells and in serum, they are rapidly degraded mostly by means of a 3' exonuclease activity. On the other hand, replacement of phosphodiester linkages by analogs that increase oligonucleotide stability, such as methylphosphonates or phosphorothioates, may result in a significant loss of affinity or specificity. One advantage of the decoy approach, compared to antisense or antigene strategies, is that double-stranded oligonucleotides are considerably more stable than single stranded molecules ${ }^{39}$. Phosphodiester double-stranded oligonucleotides may be further stabilized by designing hairpin or dumbbell-shaped structures. Dumbbell molecules are circular oligonucleotides in which the complementary strands are connected by linker loops at both ends. The hairpin and dumbbell structures provide increased stability towards nuclease degradation when compared to unlinked double-stranded oligonucleotides, while displaying comparable affinities for target binding. Tenofovir disoproxil fumarate (Gilead) is a nucleotide analogue reverse transcriptase inhibitor used as as HIV-1 drug. In vitro tenofovir $\mathrm{IC}_{50}$ was in the range of $0.04-8.5 \mu \mathrm{M}$. The anti HIV-1 drugs used so far have shown various side effects. Patients who are taking anti-HIV drugs have suffered these drug toxicities for a long time. Dosages and combinations of drugs can be chosen so they don't kill the person, but they still can't be used at their most effective concentrations against HIV.

Thus, in order to develop more effective drug for retro virus infection we have investigated binding of dumbbell oligonucleotides to MoMuLV Reverse Transcriptase and inhibitory properties of RNase $\mathrm{H}$ activity with dumbbell oligonucleotides containing loops of various chemistry. Althoug the catalytic activity of RNase $\mathrm{H}$ is restricted to RNA-DNA hybrids but enzymes can bind to different duplexes including DNA-DNA ones. As circular oligonuceotides display significant nuclease resistance ${ }^{14}$ they should be considered as good candidates to design RNase $\mathrm{H}$ inhibitors. We report here data on the design of circular (dumbbell) oligonucleotides that aimed at inhibiting RNase $\mathrm{H}$ activity. Our studies showed that dumbbell oligonucleotide containing phosphorthioate bonds in the loops displays an $\mathrm{IC}_{50}$ of $18 \mathrm{nM}$ in its inhibition on the reverse transcriptase RNase $\mathrm{H}$ activity, a magnitude lower than that of first nucleotide reverse transcriptase of HIV-1, tenofovir, introduced by Gilead Science in the market.

\section{Experimental}

Moloney Murine Leukemia Virus (MoMuLV) reverse transcriptase (RT) was purchased from Gibco -BRL. The concentration of protein, determined from its specific activity provided by the supplier, was $7.6 \mathrm{pmol} / \mathrm{uL}$. The oligonucleotides (Table 1) were synthesized on Millipore Expedite synthesizer by standard phosphoramidite chemistry. In oligonucleotides OL-3 and OL-4 using the phosphoramidite "1" (Scheme 1) two and three trimethylene, $\mathrm{C}_{3}$ moieties were added in each loop respectively ( Scheme 1). A phosphate group was introduced at the 5'-end by 2 (2'(4,4'-dimethoxytrityloxy )ethylsulfonyl ) ethyl (2-cyanoethyl)- $N, N^{\prime}$-diisoproyl phosphoramidite. The phosphorothioate part of the chimeric oligonucleotide OL-5 was synthesized by oxidizing phosphite diester bond to phosphorothioate by Beaucage reagent ${ }^{15}$. 


\section{Synthesis of dumbbell oligonucleotides}

The oligonucleotides were purified by electrophoresis on $20 \%$ polyacryamide gel containing $7 \mathrm{M}$ urea. The upper bands corresponding to the longest oligomer, visualized by UVshadowing were cut out. The gel pieces were socked in water: methanol $(80: 20 \mathrm{v} / \mathrm{v})$ mixture overnight and volume was reduced to $100 \mu \mathrm{L}$. Finally, the oligonucleotides were desalted on a Sephadex G 50 Column. The oligonucleotides (OL-2 to OL-5) were internally labeled with ${ }^{32} \mathrm{P}$ by exchange of $5^{\prime}$-phosphoryl group as described ${ }^{16}$. The spacers used for the synthesis of oligonucleotides are shown in Scheme 1. The cyclization of the oligonucleotides (OL-2 to Ol-5) was carried out as described elsewhere ${ }^{17}$. To the purified oligonucleotide (40 pmole) taken in tris buffer $(10 \mathrm{mM})$ was added to $4 \mu \mathrm{L}$ of $500 \mathrm{~m} \mathrm{M} \mathrm{NiCl} 2,24 \mu \mathrm{L} 1 \mathrm{M}$ imidazole $/ \mathrm{HCl} \mathrm{pH} 7.0$ and $4 \mu \mathrm{L}$ of $250 \mathrm{mM} \mathrm{BrCN}$. After $24 \mathrm{~h}, 4 \mu \mathrm{L}$ more $\mathrm{BrCN}$ solution was added and allowed to react further for $20 \mathrm{~h}$. The volume of mixture was made up to $100 \mu \mathrm{L}$ with water and the oligonucleotides were precipitated after addition of $200 \mu \mathrm{L}$ of dioxane and $600 \mu \mathrm{L}$ of THF. The oligonucleotides thus obtained were purified by running a $20 \%$ PAGE$7 \mathrm{M}$ urea and finally desalted by passing through a Sephadex G-50 column.

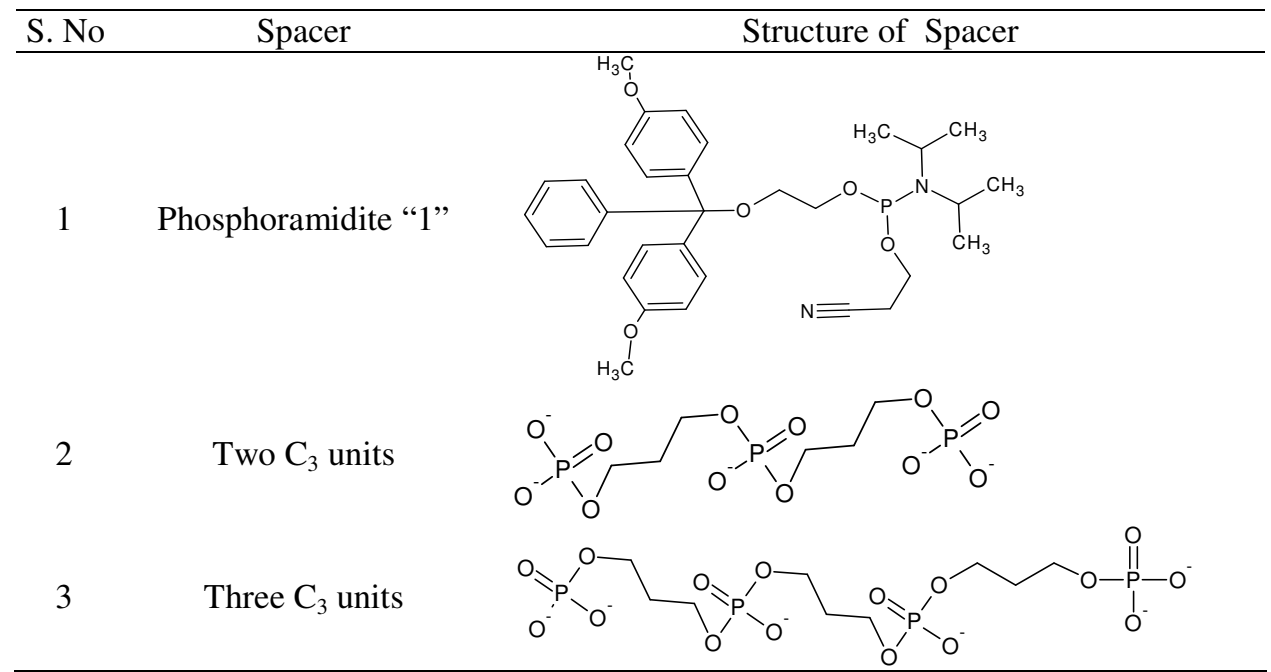

\section{Scheme 1.}

Treatment with nuclease S1

Reaction mixtures contained $10 \mathrm{mM}$ of radioactive labeled dumbbell oligonucleotide (105 cpm/mg), $50 \mathrm{mM} \mathrm{NaCl}, 33 \mathrm{mM}$ sodium acetate $\mathrm{pH} 4.4,30 \mathrm{mM} \mathrm{ZnSO}_{4}$ and 1 unit of S 1 nuclease in a final volume of $25 \mathrm{~mL}$. After incubation at $37{ }^{\circ} \mathrm{C}$ for $20 \mathrm{~min}$, the reaction was stopped by adding $20 \mathrm{mM}$ EDTA, $0.3 \mathrm{M}$ sodium acetate and $20 \mathrm{mg}$ glycogen; oligonucleotides were then precipitated with ethanol. After washing and drying, the DNA pellets were resuspended in $10 \mathrm{~mL}$ of formamide loading buffer and reaction products were analyzed by analytical $20 \%$ polyacrylamide gel containing $7 \mathrm{M}$ urea.

\section{PAGE band mobility shift assays}

Polyacrylamide gel electrophoresis band mobility shift assays were carried out as described earlier ${ }^{18}$. Complex formation between the oligonucleotide and MoMuLV RT was characterization by electrophoretic retardation of DNA as a result of its association with the enzyme. Oligonucleotide ( $2 \mathrm{pmol})$ and the indicated amount of enzyme were incubated for 10 minutes at $37{ }^{\circ} \mathrm{C}$ in $10 \mathrm{mM} \mathrm{KCl}$ (final volume, $10 \mu \mathrm{L}$ ). The enzyme oligonucleotides 
mixtures were electrophoresed through a $5 \%$ non -denaturing polyacrylamide gel in $1 \mathrm{X}$ TBE at $4{ }^{\circ} \mathrm{C}$ under $10 \mathrm{~V} / \mathrm{cm}$ for $2-3 \mathrm{~h}$. After electrophoresis the gel was dried and subjected to autoradiography. Finally, the formation of complex between the RT and the labeled oligonucleotide was quantified by measuring radioactivity in cut bands of the gel. The binding constant $\mathrm{Ka}$ was evaluated from the MoMuLV RT concentration at which $50 \%$ of the oligonucleotide was converted into oligonucleotide/RT complex: $\mathrm{Ka}=\{\mathrm{MoMuLV}$ $\mathrm{RT}$ 50-1/2 (ODN)o $\}^{-1}$. Where (OND)o is initial oligonucleotide concentration and (MoMuLV RT )50 is the enzyme concentration inducing 50\% band shift ( Figure 1).

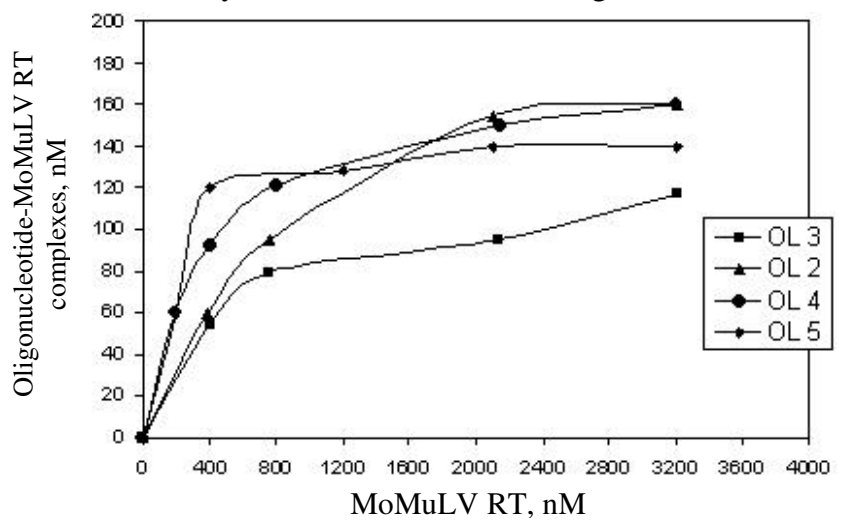

Figure 1. Binding curve of MMLV RT to duplex and dumbbell oligonucleotides.

\section{Inhibition of RNase $H$ activity of MoMuLV reverse transcriptase}

Synthesis of ${ }^{3} \mathrm{H}$-UTP-labeled RNA: RNA-DNA hybrid required for RNase $\mathrm{H}$ activity inhibition assay was prepared as described elsewhere ${ }^{19}$. The specific activity of the hybrid was about 400 $\mathrm{cpm} / \mathrm{pmol}$. The assay mixture containing the oligonucleotide (40 to $200 \mathrm{nM}$ ), the enzyme (22.5 $\mathrm{nM}$ ), the hybrid (48 pmoles) in $0.3 \mathrm{M}$ tris $-\mathrm{HCl}$, at $\mathrm{pH} 7.8,0.014 \mathrm{M}$ mercaptoethanol, $0.1 \mathrm{M} \mathrm{Mg}$ $\mathrm{Cl}_{2}$ and $0.3 \mathrm{M}\left(\mathrm{NH}_{4}\right)_{2} \mathrm{SO}_{4}$ was incubated for $10 \mathrm{~min}$ at $37^{\circ}$, chilled on ice. Then, $25 \mu \mathrm{L} t$-RNA $(12 \mathrm{mg} / \mathrm{mL}$ ) were added, prior to precipitation by $250 \mathrm{uL} 8 \%$ TCA solution. The mixture was kept on ice for $10 \mathrm{~min}$ then centrifuged for $10 \mathrm{~min}$ at $4{ }^{0} \mathrm{C}$. The supernatant was kept with $5 \mathrm{~mL}$ of scintillation fluid and counted in Beckman beta scintillation counter. After subtraction of the blank value (about $100 \mathrm{cpm}$ ) from an assay without enzyme and oligonucleotide, the percentage inhibition was determined from TCA -precipitable material. Finally percentage Rnase H inhibitions were plotted against oligonucleotides concentration (Figure 2).

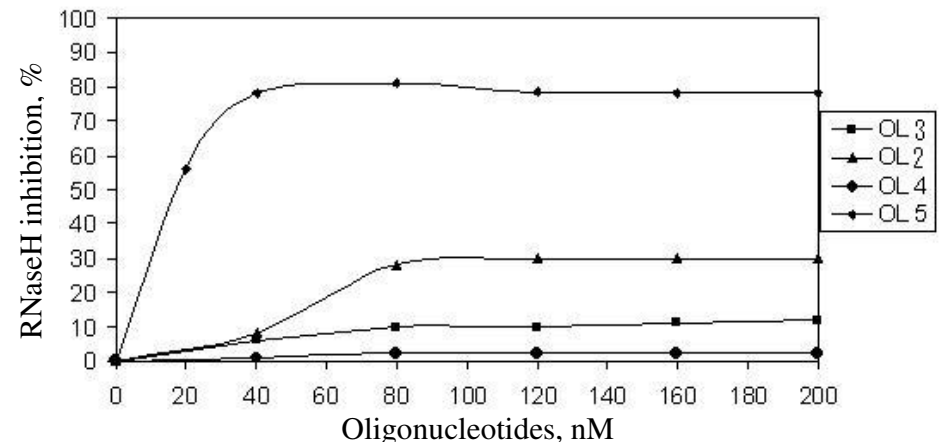

Figure 2. Inhibition of RNase H activity of MoMuLV RT by dumbbell oligonucleotides. 


\section{Results and Discussion}

Oligonucleotides synthesized as potential inhibitors of reverse transcriptase RNase $\mathrm{H}$ displayed a double -stranded portion, 12 base pair of long of random sequence (Table 1). In order to ensure a higher stability of duplex , the two strands were linked to each other, thus generating so called dumbbell oligonucleotides which have been previously used as decoys to titrate out transcription factors ${ }^{14,22-29,36}$ and topoisomerase ${ }^{37}$. The dumbbell OL-2 was prepared with two loops made of $5 \mathrm{~T}$ containing phosphodiester bonds. However, even though 3 '-exonucleases are the most abundant DNase in biological media ${ }^{20}, \mathrm{OL}-2$ will still is degraded by endonucleases. Indeed, incubation of OL-2 with S1 nuclease generated breakdown products as seen by electrophoretic analysis on a denaturing polyacrylamide gel. Therefore we prepared dumbbell with nuclease resistant loops. This was achieved in two different ways: in OL-5 the 5 $\mathrm{T}$ connections were introduced as phosphorothioate analogs whereas OL-3 and OL-4 contain trimethylene phosphates (C3) segments. In this latter case two different loop sizes were used: OL-3 and OL-4 have two and three C3 motifs, respectively.

We then monitored the binding of MoMuLV reverse transcriptase to the various oligonucleotides using electrophoretic mobility shift assay under the conditions described in in the experimental section. The addition of RT to ${ }^{32} \mathrm{P} 5^{\prime}$ end labeled oligomers resulted in the appearance of slow migrating species corresponding to protein-oligonucleotide complexes. The oligonucleotide amount in free and bound forms was determined by scintillation counting as described in the experimental section. Figure 1 shows that all five oligonucleotides bind to the protein with similar affinities. The dissociation constant, evaluated from the titration curves fall in the micro molar range (Table 1). The oligomer OL-3 shows a significantly lower affinity than either OL-2 or OL-4, this is likely related to the size of the connecting loop: the link might be too short and introduce constraints in the closed oligomer, altering the double stranded ness character of dumbbell and consequently, its binding to the reverse transcriptase. We next compared the inhibitory properties of dumbbell oligonucleotides to the RNase $\mathrm{H}$ activity of reverse transcriptase. As shown in Figure 2, substantial differences were observed. Trimethylene bridge -containing derivatives OL-3 or OL-4 were poor inhibitor whereas the 5T-loop dumbbells blocked RNaseH, the phosphorothioate derivative being far the most efficient Therefore, the inhibitory properties were not related to the affinity of the oligomer for the reverse transcriptase.

Table 1. Sequence of Dumbbell Oligonucleotides.

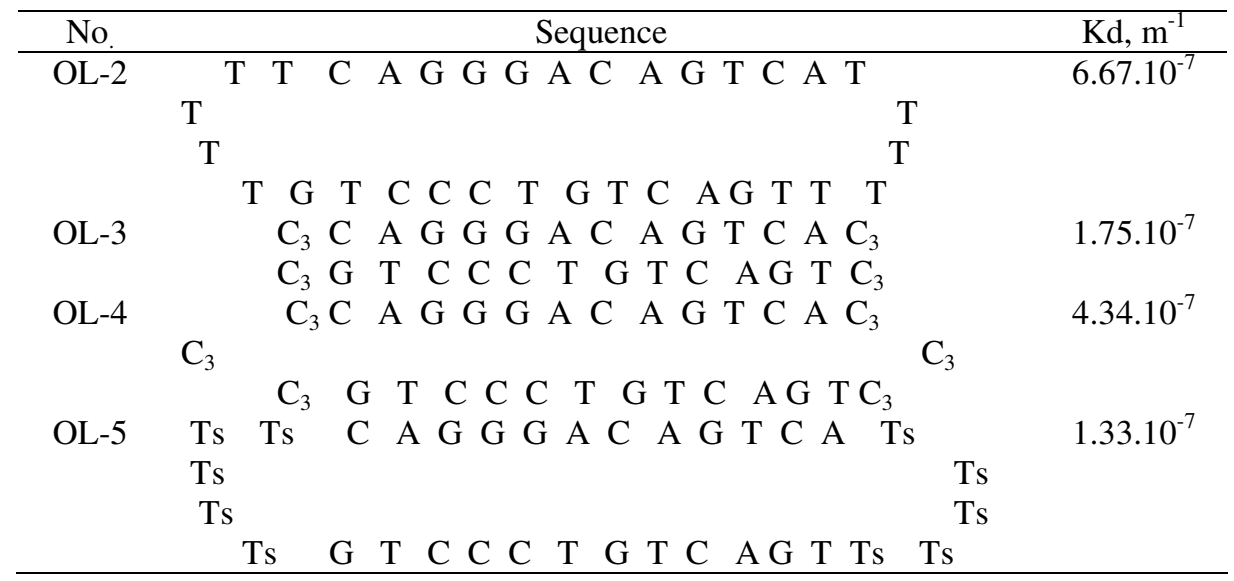

${ }^{*} C_{3}$ in $\mathrm{OL}-3$ and $\mathrm{OL}-4$ indicates trimethylenene groups. Ts denotes phosphorothioate linkage in loops of $\mathrm{OL}-5$. 
The inhibition was mainly related to the loop chemistry. This suggests either a direct interaction of the loop with the catalytic site or a conformation change of the enzyme induced upon binding. We favor the first hypothesis as indeed phosphorothioate have been shown to inhibit RNase $\mathrm{H}$ activity ${ }^{21}$. Our studies showed that dumbbell oligonucleotide containing phosphorthioate bonds in the loops displays an $\mathrm{IC}_{50}$ of $18 \mathrm{nM}$ in its inhibition on the reverse transcriptase RNase $\mathrm{H}$ activity, a magnitude lower than that of first nucleotide reverse transcriptase of HIV-1, tenofovir, introduced by Gilead Science in the market. Therefore, this investigation suggests that dumbbell oligonucleotide containing phosphorothioate linkages can be used as RNase $\mathrm{H}$ inhibitor and might be useful to interfere with retroviral cDNA synthesis.

\section{References}

1. Champoux J J, Reverse Transcriptase; Skalka A M and Golf S P: Cold Spring Harbor Laboratory Press: Cold Spring Harbor, 1993, 103.

2. Hostomsky Z, Hostomska Z and Mathews D A, In Nucleases; Cold Spring Harbor Laboratory Press, 1993, 341.

3. Drug Databank, University of Alberta.

4. Helene C and Toulme J J, Biochim Biophy Acta., 1990, 1049, 99.

5. Matsukura M, Zon G, Shinozuka K, Robert-Guroff M, Shimada T, Stein C A, Mitsuya H, Wong -Staal F, Cohen J S and Broder S, Proc Natl Acad Sci USA., 1989, 86, 4244.

6. Goodchild J, Agrawal S, Civeira M P, Sarin P S, Sun D and Zamecnik P C, Proc Natl Acad Sci USA., 1988, 85, 5507.

7. Boiziau C, Thuong N T and Toulme J J, Proc Natl Acad Sci USA., 1992, 89, 786.

8. Sarver N, Cantin E M, Chang P S, Jzaia J A, Lande P, Stephens D A and Rossi J J, Science, 1990, 247, 1222.

9. Volkmann S, Dannull J and Moelling K, Biochimie, 1993, 75, 71.

10. Giovannangeli C, Thuong N Tand Helene C, Nucleic Acids Res., 1992, 20, 4275.

11. Chaix C, Toulme J J, Morvan F, Rayner B and Imbach J L, Antisense Research and Application; Lebleu B and Crooke S T: CRC: Boca Raton, 1993, 224.

12. Marshall W S and Caruthers M H, Science, 1993, 259, 1564.

13. Tuerk C, Macdougal S and Gold L, Proc Natl Acad Sci USA., 1992, 89, 6988.

14. Clusel C, Ugarte E, Enjolras N, Vasseur M and Blumenfeld M, Nucleic Acids Res., 1993, 21, 3405.

15. Iyer P I, Lawrence R P, Egan W J, Regan J B and Beaucage S L, J Org Chem., 1990, 55, 4693.

16. Chaconas G and Van deSande J H, Methods in Enzymology; S.P. Colowick S P and Kaplan N O: Academic Press: New York, 1980, 75.

17. Pannekouke X, Helvetica Chemica Acta., 1994, 77, 182.

18. Boiziau C, Larrouy B, Sproat B and Toulme J J, Nucleic Acids Res., 1995, 23, 64.

19. Cazenave C, Frank P and Busen W, Biochimie, 1993, 75, 113.

20. Verspieren P, Cornelissen A W C A, Thuong N T, Helene C and Toulme J J, Gene, 1987, $61,307$.

21. Gao W Y, Han F S, Strom C, Egan W and Cheng M Y C, Mol Pharmacol., 1992, 41, 223.

22. Devine-Beach K, Haas S and Khalili K, Nucleic Acids Res., 1991, 20, 5455

23. Bielinska A, Shivdasani R A, Zhang L and Nabel G J, Science, 1990, 250, 997.

24. Clusel C, Ugarte E, Enjolras N, Vasseur M and Blumenfeld M, Nucleic Acids Res., 1993, 21, 3405.

25. Tanaka H, Vickart P, Bertrand J R, Rayner B, Morvan F, Imbach J L, Paulin D and Malvy C, Nucleic Acids Res., 1994, 22, 3069. 
26. Riabowol K, Schiff J and Gilman M Z, Proc Natl Acad Sci., USA 1992, 89, 157.

27. Eck S L, Perkins N D, Carr D P and Nabel G J, Mol Cell Biol., 1993, 13, 6530.

28. Voso M T, Burn T C, Wulf G, Lim B, Leone G and Tenen D G, Proc Natl Acad Sci USA., 1994, 91, 7932-7936.

29. Morishita R, Gibbons G H, Horiuchi M, Ellison K E, Nakajima M, Zhang L, Kaneda Y, Ogihara T and Dzau V J, Proc Natl Acad Sci ., USA, 1995, 92, 5855.

30. Shibuya T, Takei Y and Hirose M, Biochem Biophys Res Commun., 2002, 298, 10.

31. Novina C D, Murray M F, Dykxhoorn D M, Beresford P J, Riess J, Lee S K, Collman R G, Lieberman J, Shankar P and Sharp P A, Nat Med., 2002, 8, 681.

32. Park K G, Ryu S Y and Lee I, Biochem Biophys Res Commun., 2003, 308, 689.

33. Ahn J D, Kim C H, Magae J, Kim Y H, Kim H J and Park K K, Gene Ther., 2002, 9, 1682.

34. Ahn J D, Morishita R and Kaneda Y, Circ Res., 2002, 90, 1325.

35. Clusel C, Ugarte E, Enjolras N, Vasseur M and Blumenfeld M, Nucl Acids Res., 1993, 21, 3405.

36. Hosoya T, Takeuchi H, Kanesaka Y, Yamakawa H, Miyano- Kurosaki N, Takai K, Yamamoto N and Takaku H, FEBS Lett., 1999, 461, 136.

37. Magdeline Tao, Tao Ng and Tianhu Li, The FASEB Journal, 2008, 22, 593.

38. Kim J C, Lee S H, Cheong Y H, Yoo C M, Lee S I, Chun H J, Yun D J, Hong J C, Lee S Y and Lim C O, Nucl Acids Res., 1997, 25, 689.

39. Herdewijn P, Oligonucleotide Synthesis, Methods and Applications; Humana Press, 2005. 


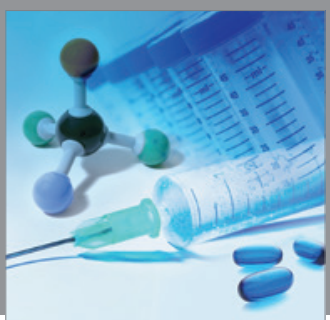

International Journal of

Medicinal Chemistry

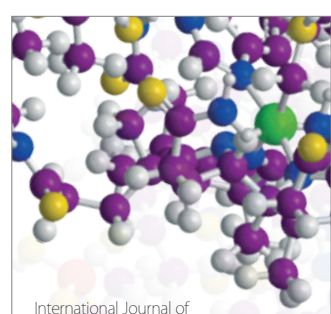

Carbohydrate Chemistry

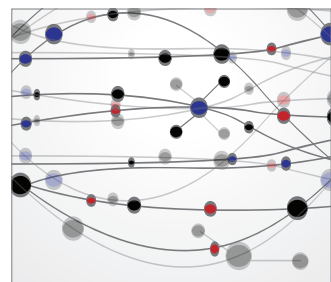

The Scientific World Journal
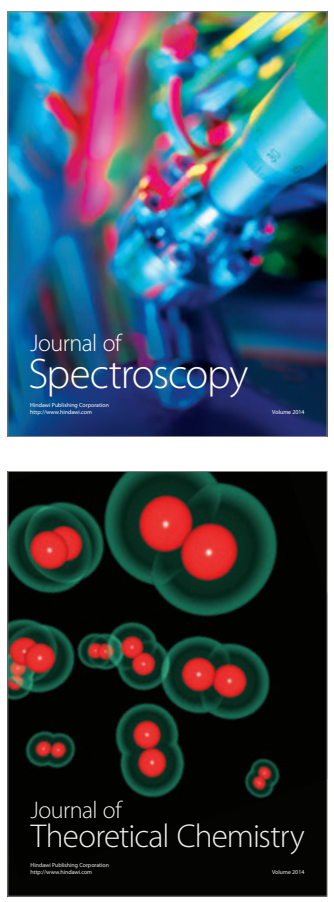
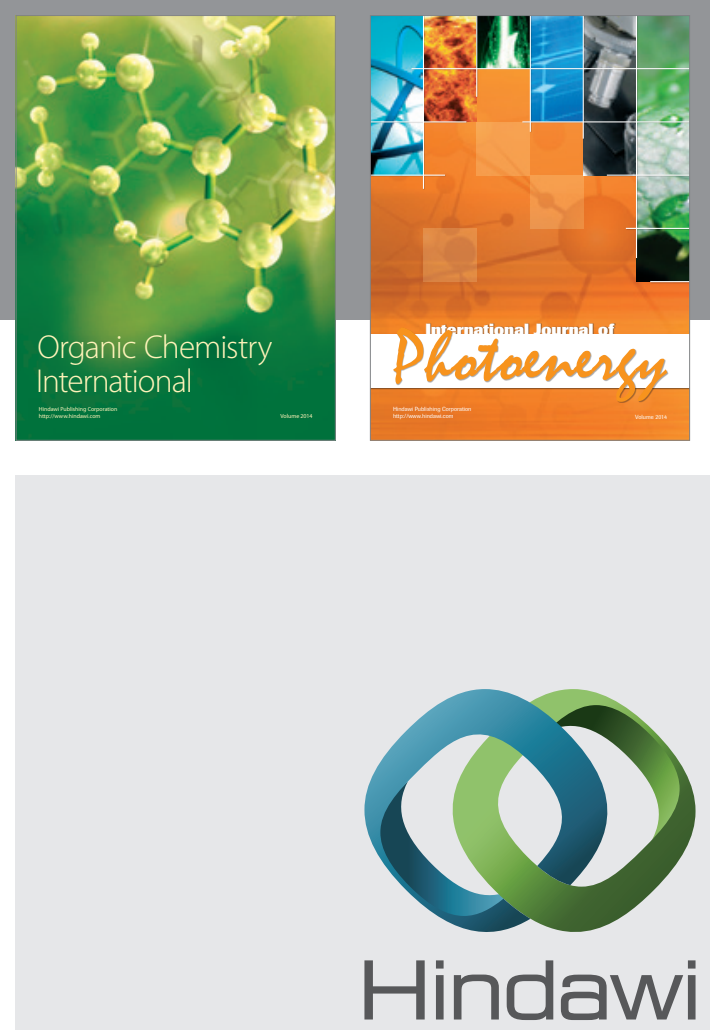

Submit your manuscripts at

http://www.hindawi.com
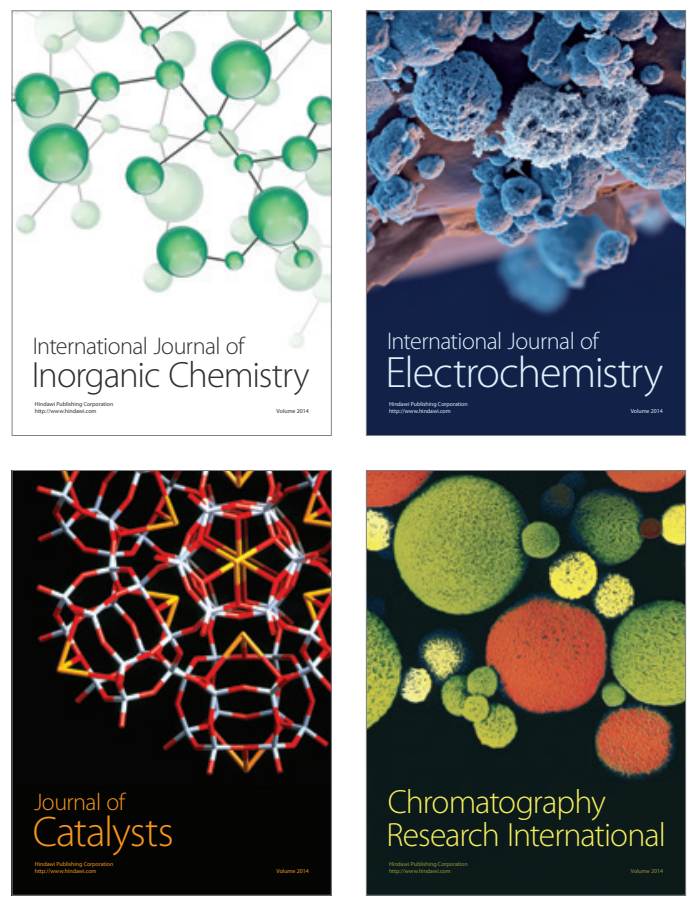
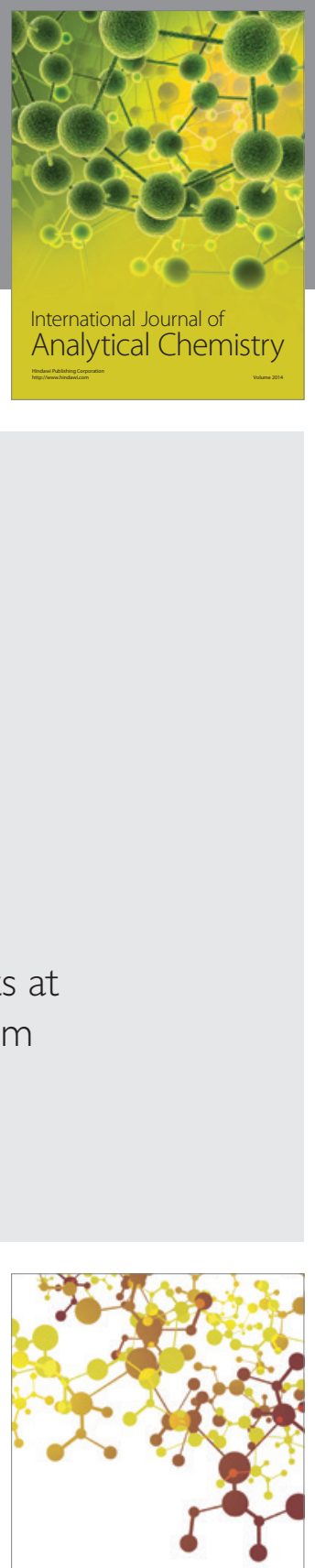

Journal of

Applied Chemistry
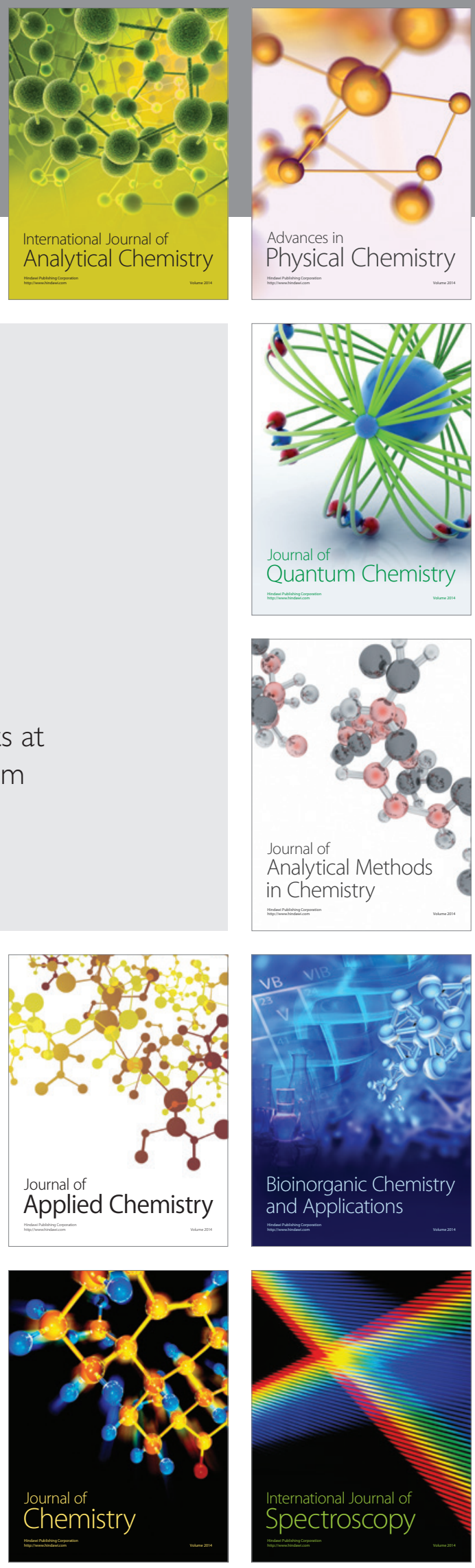